\title{
REFLEXÕES DE LEITURA SOBRE AS POÉTICAS DA MARQUESA DE ALORNA E DE MARIA TERESA HORTA
}

\author{
READING NOTES ABOUT THE POETIC WORKS OF \\ MARQUESA DE ALORNA AND MARIA TERESA HORTA
}

\begin{abstract}
Resumo
A Marquesa de Alorna (1750-1839) e Maria Teresa Horta (1937) fazem parte de uma genealogia feminina constituída não só por laços de sangue, mas por ousadias poéticas e biográficas construídas na contramão do que a sociedade espera(va) das mulheres. Neste trabalho, evidenciam-se diálogos que Maria Teresa Horta e a Marquesa de Alorna estabelecem entre si e com a tradição lírica portuguesa. Nesse sentido, sob o amparo do método comparativista, traça-se uma breve trajetória biográfica das autoras e elabora-se uma análise de temas recorrentes nas suas poéticas, mesmo que alguns se apresentem de forma diversa em cada uma das obras: $\mathrm{o}$ amor (sua negação ou sua invocação); a tradição e a ruptura; o engajamento político.
\end{abstract}

Palavras-chave: Marquesa de Alorna. Maria Teresa Horta. Lírica feminina. Tradição. Ruptura.

\begin{abstract}
Marquesa de Alorna (1750-1839) and Maria Teresa Horta (1937) are part of a female genealogy established not only with blood laces, but wit poetic innovation and biographical boldness and built on the contraflow of society expectation for women. This essay establishes some relation between Marquesa de Alorna and the contemporary Portuguese poet, Maria Teresa Horta and among these two writers and the tradition of Portuguese lyrics. To achieve this, using the comparative method, it is necessary to understand the biographical trajectory of both writers and also to develop a brief analysis of recurrent themes on their work, even though, some of these themes appear in different perspectives in each one. The main themes are love (denying and invocation); tradition and rupture; politic commitment.
\end{abstract}

Keywords: Marquesa de Alorna. Maria Teresa Horta. Female lyrics. Tradition. Rupture.

\section{Conceição Flores}

Universidade Potiguar (UnP).

E-mail: cflores@unp.br

Ilane Ferreira Cavalcante

Instituto Federal do Rio Grande do Norte (IFRN).

E-mail: ilane.cavalcanti@ifrn.edu.br 


\section{Introdução}

Sigo as rotas

da poesia

com versos

teço a vassoura

de feiticeira arredia

a enredar-se nas rimas

e sonetos onde voa

Maria Teresa Horta

Os versos da poetisa contemporânea Maria Teresa Horta traçam uma rota de afirmação da sua adesão a uma tradição feminina que implica na revisão dos papeis femininos na história e na literatura. Bruxa, ela alça voo em busca de uma tradição literária que a identifique enquanto mulher e poetisa. E uma das âncoras dessa tradição é a Marquesa de Alorna de quem tem o "[...] sangue nas veias / e na poesia" (HORTA, 2012: p. 30).

D. Leonor de Almeida Portugal, 4a Marquesa de Alorna, é uma das raras mulheres a figurar nas histórias da Literatura Portuguesa ${ }^{1}$, dado que revela o lugar que ela ocupa no cânone literário português. Essa condição, contudo, não assegurou à sua poesia um lugar de destaque entre pesquisadores e leitores, fosse porque a sua obra, publicada em 1844, durante muitos anos permaneceu esgotada, fosse porque os temas abordados na sua poética não suscitassem mais o mesmo interesse de outrora (ANASTÁCIO, 2007, p. 11).

Em 2011, a Marquesa de Alorna ganhou notoriedade em Portugal pela mão de Maria Teresa Horta, sua quinta neta. A publicação do monumental romance As luzes de Leonor, a marquesa de Alorna, uma sedutora de anjos, poetas e heróis não só põe em cena a trajetória da protagonista - desde 1754, ano em que os Marqueses de Távora, avós maternos de Leonor, regressaram da Índia, a 1803, ano do exílio da Marquesa de Alorna - como também dá visibilidade à poesia da "sedutora de anjos, poetas e heróis". Abrindo cada um dos 25 capítulos do romance, um poema de D. Leonor, dos quais 9 são sonetos.

Durante os 13 anos de escrita do romance, Maria Teresa Horta foi também escrevendo poesia inspirada pela Marquesa de Alorna, textos que foram reunidos no livro Poemas para Leonor, publicado em 2012.
Neste artigo, traça-se um paralelo entre a poesia da Marquesa de Alorna e a de Maria Teresa Horta sob a perspectiva de cantos paralelos, como duas vozes que soam em tempos e espaços distintos, mas que carregam em si traços de liberdade e de subversão, que avalizam a construção de uma linha de tradição feminina na literatura de língua portuguesa.

Na poética da Marquesa de Alorna, o soneto ganha importância singular, por ter sido a principal forma poética desenvolvida pela poetisa. Nascido na Itália medieval, o soneto era, então, forma poética nova que carregava os valores do dolce stil nuovo, valorizando a expressão amorosa de caráter sublime em um formato bastante enxuto para a época, apenas 14 versos estruturados, regra geral, em decassílabos e divididos em dois quartetos e dois tercetos. O soneto petrarquista ${ }^{1}$, que seguirá para Portugal pelas mãos de Sá de Miranda, foi cultivado por Camões, que o privilegiou em suas composições líricas e seguiu sendo uma forma poética de eleição para inúmeros escritores de língua portuguesa, tais como Bocage, Antero de Quental e Florbela Espanca. A Marquesa de Alorna, na linha dessa tradição poética e leitora dos sonetos camonianos, inicia sua obra privilegiando essa forma, embora também tenha escrito odes, idílios, epístolas e fosse exímia na técnica do improviso e da glosa, como afirma Vanda Anastásio (2007).

Liberta da forma fixa e do verso de sílabas contadas, Maria Teresa Horta assume uma postura diferente de sua ancestral, principalmente porque o tempo em que vive the permite, poeticamente, maior ousadia. Senhora de uma lírica inovadora, que dialoga ousadamente com a tradição medieval das cantigas de amigo, explora com liberdade a musicalidade das formas, causando impacto por assumirse como sujeito desejante e ousar com o predomínio de temas tabus, como o gozo, a menstruação, o desejo feminino. Mas, se a ousadia é uma de suas marcas, ela tem na sua quinta avó uma figura tutelar, conforme se constata no poema "Astuciosa".

1 Embora não tenha sido Petrarca (1304-1374) o primeiro a compor sonetos, é a ele que se deve a forma e o conteúdo que se tornariam modelos seguidos pela posteridade, não só na Itália, mas também em outros países da Europa. 


\author{
Porque eu uso \\ palavras sequiosas \\ E tu astuciosa no limite \\ Levas-me a voar \\ e a tombar \\ Sem conseguir deixar \\ De perseguir-te \\ (HORTA, 2012, p. 62)
}

\section{De Leonor a Teresa - nas veredas de uma tradição feminina}

Nascida em Lisboa, em 1750, D. Leonor de Almeida Portugal Lorena e Lencastre é a primeira filha de D. João de Almeida Portugal, $4^{\circ}$ Conde de Assumar e $2^{\circ}$ Marquês de Alorna, e de D. Leonor de Lorena e Távora. Neta dos Marqueses de Távora, a quem foi imputado o regicídio contra D. José, D. Leonor teve a infância marcada pela tragédia que caiu sobre a sua família. Em 1758, os avós foram executados em praça pública, o pai, encarcerado na prisão da Torre de Belém, e D. Leonor, a irmã e a mãe, encerradas no convento de Chelas.

Cresceu no convento, tendo a sua educação sido acompanhada pelo pai, que, por meio de cartas à esposa e à filha, guiava os seus estudos e suas leituras ${ }^{2}$. O fato de ter sido preservada documentação da Casa de Fronteira e Alorna permite conhecer a educação que D. Leonor e a irmã receberam. Assim, sabe-se que estudaram inglês e latim, o que, na época, não era usual na educação das meninas. Outros documentos importantes são as cartas enviadas por D. Leonor ao pai e à Condessa do Vimieiro, D. Teresa de Mello Breyner (ANASTÁCIO, 2007, p. 21, 22).

$\mathrm{O}$ interesse pela poesia ocorreu desde muito cedo na vida de D. Leonor. O primeiro soneto teria sido escrito aos 15 anos, conforme indicação autógrafa em manuscrito. Afirmava que "[...] começou a escrever poesia para distrair seu pai das agruras do cárcere e para desafogar o seu sofrimento [...]" (ANASTÁCIO, 2007, p. 23). No convento, em ocasiões especiais, eram realizados outeiros poéticos, dos quais ela participava. A sua participação nesses eventos contribuiu para a sua formação e para o manejo exímio da arte de versificar.

A formação intelectual da Marquesa de Alorna, além dos conselhos paternos, contou com a solidariedade de poetas e amigos que circulavam pelo convento. Entre eles, Filinto Elíseo, poeta da Arcádia Lusitana, responsável pela atribuição do nome árcade de Alcipe a D. Leonor; além disso, faziam parte desse grupo de amigos a Condessa do Vimieiro e Joana Isabel de Lencastre Forjaz, escritoras que frequentavam a sociedade letrada de Lisboa.

Embora D. Leonor tenha tido a sua formação intelectual iniciada pela orientação paterna, mais tarde seguiu as indicações de leitura da Nouvelle Bibliothèque d'un homme de goût e também começou a ter acesso aos livros que iam sendo publicados, pois havia feito um acordo com livreiros que lhe emprestavam os livros em troca de um pagamento mensal (ANASTÁCIO, 2007, p. 22).

Em 1777, com a morte de D. José e o fim da era Pombal, as portas dos conventos e das prisões se abriram para as vítimas do déspota esclarecido. Enfim, a família Alorna se reunia passados 18 anos. D. Leonor era, então, uma jovem de 27 anos, com uma formação intelectual rara para uma senhora daquele tempo. Tendo passado a maior parte da sua vida encarcerada, aproveitara o tempo com leituras e, naquele momento, ansiava, provavelmente, por conhecer o mundo. Mas o pai manteve a família longe da corte, pois desejava ver reconhecida pela rainha a inocência dele e dos Távoras no regicídio.

Casou, contra a vontade do pai, em 15 de fevereiro de 1779, com o Conde alemão Carlos Augusto de Gravenburg Oyenhausen, um estrangeiro de religião luterana e com "recursos financeiros duvidosos" (ANASTÁCIO, 2007, p. 25). O conde foi batizado antes da cerimónia matrimonial, tendo sido seus padrinhos D. Maria I e D. Pedro III. D. João de Almeida Portugal, pai de D. Leonor, determinava no contrato de casamento que a filha não poderia sair do reino "[...] excepto se a Raynha minha Senhora achar o contrário em alguma ocasião conveniente ao seu real Serviço." (apud ANASTÁCIO, 2007, p. 27).

Em abril de 1780, o casal seguiu para Viena, onde o conde assumiria o cargo de Ministro Plenipotenciário na corte de Viena. Em 1785, por motivos financeiros, a família, que já contava com duas filhas, seguiu para o sul da França e D. Leonor deslocou-se a Lisboa, sozinha, com o objetivo de angariar meios para sanar as dificuldades financeiras em que se encontrava. Com a nomeação do marido como Tenente-Coronel de Infantaria, em data que 
não se pode precisar, mas que ocorreu entre 1790 e 1792 (cf. ANASTÁCIO, 2007, p. 38), a família regressou a Portugal. E, em 3 de março de 1793, o marido faleceu.

A Marquesa de Alorna, de 1793 a 1802, manteve estreitas relações intelectuais com poetas da Nova Arcádia, como Francisco Joaquim Bingre. Desse período também é o relacionamento literário com D. Catarina Micaela de Lencastre, Viscondessa de Balsemão, e com Manuel Maria Barbosa du Bocage, conforme atestam poemas trocados entre ambos.

A presença da autora nos livros que traçam a historiografia da literatura portuguesa é, no entanto, breve. Saraiva e Lopes (1985, p. 693) colocam-na em capítulo dedicado à irradiação e evolução da poesia árcade. Sobre ela, apontam a "rasgada cultura"; sobre a obra poética, sinalizam "um misto de tendências diversas" e as versões pré-românticas de sua "poesia cientista $[\ldots]$ e um certo número de composições funebremente sentimentais ou insinuantemente melancólicas".

Massaud Moisés também trata muito brevemente da autora, situando-a como pré-romântica, no grupo dos poetas que, negando a Arcádia, fundaram agremiações de caráter mais rebelde e insatisfeito. Ele a considera "[...] importante pela vida que levou e pela atividade sócioliterária que exerceu", mas enfatiza que sua obra literária foi posta "em segundo plano". Ainda informa que a sua poesia "[...] oscila entre o culto dos clássicos, alguns dos quais traduziu (Horácio e Pope) e o dos românticos, o que the confere nítido caráter pré-romântico". (MOISÉS, 1987, p. 126-127). Finalizando o conciso relato, afirma:

A Marquesa de Alorna trouxe menos novidades que José Anastácio da Cunha, embora valha muito como evidência das novas correntes literárias românticas, e sirva, por isso, de vaso comunicante entre a estética em que se educou e aquela que foi conhecendo pela vida fora. (MOISÉS, 1987, p. 127).

Fica evidente, nos dois exemplos da historiografia da literatura portuguesa, haver certo menosprezo pela obra da autora em detrimento de sua vida, além de um posicionamento de indefinição quanto à sua posição estilística que se aponta ou nos círculos árcades ou nos pré-românticos.

Em 1803, D. Leonor, então primeira dama da princesa Carlota Joaquina, foi obrigada por Pina Manique,
Intendente Geral da Polícia, a sair de Portugal. O seu envolvimento político desagradava ao Intendente Geral, que alegava o envolvimento de D. Leonor na criação de uma sociedade paramaçônica. No passaporte, a indicação era de que a viagem se destinava "[...] a bem da educação, e interesse de seu filho o Conde João Friderico Ulrico d'Oeyenhausen, que leva na sua companhia [...]" (apud ANASTÁCIO, 2007, p. 41).

Após 11 anos de exílio na Inglaterra, regressou a Portugal em julho de 1814. Estabeleceu residência em Lisboa, passando a abrir as portas da sua residência a intelectuais. A Marquesa ocupou um lugar de destaque na vida literária portuguesa até a sua morte, ocorrida aos 89 anos, em 11 de outubro de 1839.

Quanto ao título pelo qual se tornou conhecida, ele foi fruto do seu empenho em reabilitar a memória de seu irmão, o $3^{\circ}$ Marquês de Alorna, condenado por ter combatido ao lado dos exércitos de Napoleão. A cunhada e os sobrinhos já eram falecidos e ela tornou-se herdeira do título. A sua obra foi reunida postumamente pelas filhas e publicada, em seis volumes, em 1844, mas, anteriormente, circulava em cópias manuscritas que passavam de mão em mão entre os letrados de Lisboa.

Quinta neta da Marquesa de Alorna, pela linha materna, Maria Teresa Horta, nascida em Lisboa, em maio de 1937, é autora de uma vasta obra literária, cujo início remonta a 1960, ano em que publicou Espelho Inicial numa edição autoral, obra que, segundo Gastão Cruz, “[...] foi um acontecimento de cujos significados e importância não haverá hoje grande noção, curta como é a memória e a informação de muitos dos que à poesia portuguesa algum interesse dedicam" (2009, p. 12). Publicou dezenas de títulos, 29 de poesia e 8 de ficção.

Destacamos aqui livros marcantes no conjunto da obra horteana, geradores de um rumor, que ultrapassou a crítica literária e se estendeu ao campo sociopolítico. Com uma obra poética consolidada, a publicação de Minha senhora de mim (1971), livro em que o corpo tem uma centralidade, seja pelo erotismo, seja como espaço de encontro da mulher consigo mesma, provocou a burguesia e o Estado que reagiram violentamente. O livro foi logo apreendido pela PIDE (Polícia Internacional e de Defesa do Estado), órgão de repressão do governo marcelista, e a editora - a Dom Quixote - ameaçada de ser fechada se voltasse a publicar qualquer obra da escritora. Maria Teresa 
Horta passou a receber telefonemas e cartas anônimas, com ameaças, até que, numa noite, foi espancada por três homens que, entre palavrões e ameaças, lhe disseram: "isto é para aprenderes a não escreveres como escreves"3.

Em 1972, foram publicadas as Novas cartas portuguesas, obra que é uma "resposta" à cassação de Minha senhora de mim, às provocações e aos insultos de que a autora foi alvo. Escrita por três mulheres, as Três Marias - Maria Isabel Barreno, Maria Teresa Horta e Maria Velho da Costa -, o projeto surgiu durante um almoço em que as três falavam sobre a violenta reação que o livro provocara. Nessa ocasião, Maria Velho da Costa disse: "Bom, se uma mulher só faz tanto barulho, imagina três." (Apud NUNES, 2009, p. 17). O livro foi apreendido pela PIDE e as autoras processadas sob a alegação de terem "ofendido a moral”. Após a Revolução dos Cravos, em maio de 1975, o processo foi julgado e as autoras inocentadas.

Em consonância com o tempo de liberdade, saiu, em 1975, Educação sentimental, livro de poesia, em que a autora verbaliza o gozo do corpo feminino e inscreve palavras outrora não permitidas: "O clitóris", "O púbis", "A vagina", "O pênis - a haste", "Masturbação I e II", "Gozo I e II" são alguns títulos dos poemas. Considerado pela autora como um "acto de pura insubordinação", foi uma reação ao processo movido contra as Novas Cartas Portuguesas, pois, tal como a Fênix, Maria Teresa Horta renasce após cada proibição.

Em tempos de liberdade, 1987, veio a público Rosa sangrenta, livro que passou despercebido à critica e ao público, embora apresente um tema absolutamente inusitado. A menstruação, atributo biológico do sexo feminino, marca da entrada na puberdade e indicativo da vida fértil da mulher, é alçada a tema poético.

Em 1998, publicou Destino, livro de poesia, e iniciou uma intensa pesquisa sobre a Marquesa de Alorna, que daria origem ao fabuloso romance sobre essa avó distante. Quando criança, a escritora encontrara dentro de um livro uma gravura dessa avó e a mãe, um dia junto ao Tejo, contou:

- A nossa avó, que viveu há séculos e escrevia poemas, vinha até aqui onde estamos assistir ao embarque $e$ ao desembarque dos reis -. [...] E eu quedavame a imaginar essa avó descoberta a partir de uma gravura que encontrara num livro encadernado, há muito esquecido sobre a mesa baixa da nossa sala de estar. (HORTA, 2014, p. 56; grifos da autora).

E Maria Teresa Horta descreve-nos a Marquesa assim: "Olhar inteligente e arguto num rosto belo de traços delicados, os lábios de veludo toldados pelo ligeiríssimo sorriso. [...] Olhar determinado de luz, iludindo-se." (HORTA, 2014, p. 56). O fascínio que essa avó exercia sobre a menina fez a escritora perseguir durante 13 anos os passos de D. Leonor pela Torre do Tombo, onde se encontra o espólio das Casas Fronteira e Alorna ${ }^{4}$, pelo Palácio Fronteira e Alorna, que abriga parte da correspondência da Marquesa de Alorna, e por diversas bibliotecas portuguesas. Pesquisou o que até então se escrevera sobre a marquesa e trocou impressões com diversos investigadores, entre eles Vanda Anastácio, que vem há anos pesquisando a vida e a obra de Alcipe.

O leitor acompanha, ao longo das 1065 páginas de As luzes de Leonor, a marquesa de Alorna, uma sedutora de anjos, poetas e heróis (2011), a história de uma personagem fascinante, cuja vida se entrelaçou com destacados personagens históricos e literários da segunda metade do século XVIII e das primeiras décadas do XIX, entre eles, a rainha D. Maria I, Madame de Staël, o poeta árcade Filinto Elíseo, as escritoras Teresa de Mello Breyner e Catarina de Lencastre.

Com um plano arquitetural engenhoso, o romance apresenta 25 capítulos que têm sempre a mesma estrutura: um poema de abertura - todos da Marquesa de Alorna e três partes: (1) "Raízes", textos protagonizados, majoritariamente, pela Marquesa de Távora, e que versam sobre a tragédia dos Távoras, origem dos 18 anos durante os quais D. Leonor e sua família ficaram prisioneiros; (2) "Memória", texto em $1^{\mathrm{a}}$ pessoa, em que a protagonista evoca e recria o passado; (3) indicação cronológica dos acontecimentos narrados, sempre iniciados pela narradora heterodiegética que, em todos os capítulos, também cede a voz a diversos personagens, que assumem a narrativa em primeira pessoa.

Em 2012, é publicado Poemas para Leonor, livro escrito paralelamente ao romance, onde se cruzam personagens, tempos e espaços vividos por Leonor, revividos no romance, pois Maria Teresa Horta é “[...] 
neta, detetive, espia, atrás de Leonor, seguindo as suas pegadas, os seus passos, pondo o [...] pé na marca deixada pelo seu..." (VASCONCELOS, 2012, p. 10). É um transbordamento de escrita, unindo "Gerações femininas", "pelos sangues /[...] [e] pelas palavras" (HORTA, 2012, p. 127).

Seguindo essas pegadas, este trabalho se debruça em alguns dos poemas da Marquesa de Alorna e de Maria Teresa Horta, percebendo pontos de encontro e de conflito nessa relação não só de consanguinidade, mas também de herança literária.

\section{Laços de sangue e palavra - nas entrelinhas}

\section{dos versos}

Ao longo deste tópico, analisam-se os poemas de D. Leonor e de Maria Teresa Horta a partir de eixos que, como prismas, refletem e refratam a relação estabelecida entre as duas escritoras, demonstrando uma tradição que se constrói a partir de um diálogo em que a negação do estabelecido e a ruptura sobressaem.

Segundo Vanda Anastácio (2007), Alcipe escreveu 110 sonetos, 47 deles no período em que permaneceu encarcerada no convento. Essa forma poética terá sido a do seu aprendizado e Camões, o seu mestre. Mas é interessante notar também a independência de D. Leonor e o seu afastamento de poetas já consagrados. Ela escreve ao pai e afirma:

Estou vendo que V. Exa . não há-de gostar nada do meu Poema da Morte, porque é feito em verso solto. Nem o exemplo de Camões, de João Franco e outro me poderão resolver a rimar tal obra, por que a autoridade que um e outro se arrogaram, de falar Latim à Portuguesa, não é para se imitar. (apud ANASTÁCIO, 2007, p. 53).

Percebe-se, em seu texto, a ousadia. Não há, em D. Leonor, apenas a marca de suas influências de leitura, mas uma voz própria que se levanta para, do cárcere, compreender o mundo e representálo sob uma perspectiva que, sem abandonar seus antecessores, deixe sua marca. Em "Junto às margens de um rio", soneto escrito no cárcere, a poetisa retoma as conhecidas redondilhas "Sobolos rios que vão" e os sonetos "Doce sonho suave e soberano" e "Doces lembranças de passada glória" de Camões², percebese não só o afastamento estilístico, mas também a engenhosa retomada do tema pela jovem poetisa, que focaliza o "contente desvario".

Junto às margens de um rio docemente Com meus suspiros altercando, A viva apreensão ia pintando Passadas glórias no cristal luzente.

Mas quando nesta ideia mais contente O coração se estava recreando, Despenhou-se do peito o gosto brando, Envolto com a rápida corrente.

\section{Lá vão parar meus gostos no Oceano, Ficando inanimado o peito e frio. Que o recreio buscou só por seu dano. \\ Acabou-se o contente desvario, E meus olhos saudosos do engano Quase querem formar um novo rio.}

(ALORNA, 2007, p. 91)

As glórias do passado são rapidamente esquecidas pela poetisa e viram gosto brando que quase formam um novo rio. No entanto, em uma sociedade e um tempo em que não era permitido à mulher sequer a escolha de seus amores, Alcipe se detém no querer, que é "quase", um recurso estilístico inteligente, em que a jovem poetisa revela a sua coragem de não se entregar à tristeza.

Consciente da importância de D. Leonor na linhagem de sua tradição literária, Maria Teresa Horta se reconhece igual e diferente, por isso afirma reconhecer o rigor que cercava a produção de $\mathrm{D}$. Leonor, mas percorre o próprio caminho e, nele, arrisca seu próprio invento que não mais cede à razão, como fazia a sua avó, mas à paixão, ao fogo do corpo.

$$
\begin{aligned}
& \text { Rigor } \\
& \text { De ti sei a raiz } \\
& \text { do sentimento } \\
& \text { o lugar do rigor } \\
& \text { Rasgando a alma }
\end{aligned}
$$

2 A Professora Vanda Anastácio, na introdução aos Sonetos da Marquesa de Alorna, aponta o diálogo intertextual estabelecido pela poetisa com Camões. Cf. ANASTÁCIO, 2007, p. 55. 
Entre aquilo que és

não o sendo

no turvado olhar

Nunca se acalma

Percorro solitária

o meu invento

e se à razão tu cedes

Eu arrisco

Ao teu destino retiro

o ferro da paixão

mas do fogo do corpo

Não desisto.

(HORTA, 2012a, p.48)

A paixão, o amor, o fogo, o corpo, explorados na poesia de Maria Teresa Horta, são temas que D. Leonor viveu intensamente, mas que procurou modalizar na escrita literária. Conforme Anastácio (2007), o amor foi tema que a autora procurou tratar com recato ao longo de toda a sua vida e talvez tenha fundamento na preocupação de resguardar, conforme recomendação paterna, a reputação de seriedade e de moral irrepreensível, com a finalidade de reprimir os perseguidores de sua família. É ainda Anastácio (2007) quem nos informa que dos 110 sonetos deixados por Leonor, apenas 7 tem o amor como tema e, em geral, indicando um posicionamento de receio ou de desvalorização desse sentimento. No entanto, no soneto 46, escrito após a saída do cárcere, percebe-se que buscar fugir ou regrar o sentimento não implica, necessariamente, em conseguir esse feito:

Não vejo, não respiro, escuto ou penso Sinto só; quem não sente não m'intende Um receio fatal a voz me prende Pelas veias me corre um fogo intenso.

Ao meu fogo se opõe um gelo imenso, E quanto mais o lume em mim se acende, Mais o susto gelar-me em vão pretende, Mais luto contra amor, e menos venço.

Dize, Inconstante, dize, não te custa A desamar o que algum dia amaste? Ou fui, quando te amei, acaso injusta?

Se das Rochas de Sintra, onde juraste Eterna fé, o aspecto não te assusta, Tira delas a chama que apagaste.

(ALORNA, 2007, p. 141)
No poema, Alcipe reclama das contradições internas ao sentimento amoroso e de como é vã sua luta contra esse sentimento. Rico em antíteses, gosto bastante peculiar a seu mestre Camões, com quem dialoga ${ }^{3}$, ela confessa que ao seu "fogo se opõe um gelo imenso" e indaga ao "Inconstante" se não lhe "custa/ A desamar o que algum dia amaste?". Imperativamente, pede ao amado que tire das Rochas de Sintra, testemunhas e guardiãs desse amor, a chama que ele apagou, posto que o poema revela uma desilusão amorosa. Maria Teresa, em "Invocação ao amor", faz vários pedidos ao amado, nenhum deles relacionado à desilusão:

Pedir-te a sensação
a água
o travo
Aquele odor antigo
de uma parede
branca
Pedir-te da vertigem
a certeza
que tens nos olhos
quando me desejas
Pedir-te sobre a mão
a boca inchada
um rasto de saliva
na garganta
Pedir-te que me dispas
e me deites
de borco e os meus seios
na tua cara
Pedir-te que me olhes
e me aceites
me percorras
me invadas
me pressintas

Pedir-te que me peças que te queira no separar das horas sobre a língua (HORTA, 2012b, p. 21)

O amor, no poema de Maria Teresa Horta, ganha novos contornos, novos significados, já não há apenas um apelo ao sentimento, há uma entrega, um desejo, e o corpo é elemento que participa intensamente do envolvimento

3 Impossível esquecer o famoso soneto de Camões "Amor é fogo que arde sem se ver". 
amoroso em todas as suas nuances. O amor é agora alimento do corpo, necessidade do corpo, busca e entrega, carne e sangue. De mãos dadas com o sentimento, o gozo, por isso, a poetisa elege o prazer, e não apenas o amor, como tema:

\section{Prazer}

Vai cuidadosa a mão tão leve e torpe entornar o amor no turvo coração logo ardente aceitando a culpa breve se o fogo aceso junto ao peito ouve

Doce se avoluma então insatisfeito quanto mais amado e mais volúvel for em turbulência dor ou persistente logro pois de enamorar-se acabará suspeito

Deixa-me morder tingindo o lábio solto de carmim febril onde o pudor castiga apesar de me escusar ao insistente rogo

Mas logo o coração se entrega indecoroso mal o prazer se despe no olhar teimando só depois tornar-se venturoso (HORTA, 2009, p. 813)

Nessa linha de tradição que se estende de D. Leonor a Maria Teresa, o amor ganhou espaço na literatura e ganhou também corpo e sangue, ganhou prazer. Maria Teresa Horta acolhe o amor em toda a sua essência e em todos os seus modos. Nessa travessia, transfiguraramse os mitos. Eros, tantas vezes evitado por D. Leonor, é evocado por sua neta e muitas vezes ganha corpo em anjos de gozo e matéria. Alcipe, do cárcere, alude ao amor como importuno, contraditório, árbitro de desventuras:

Como, importuno Amor, ainda procuras Misturar-te entre as minhas agonias?

Vai, cruel, para onde as alegrias

No seio da Fortuna estão seguras.

Onde em taças douradas, formosuras, Esgotando o prazer, passam seus dias; Onde acariciado tu serias

Por quem nem sabe o nome às desventuras.

Ao som de harmoniosos instrumentos, No peito, que é de pérolas ornado, Criarás mil suaves sentimentos:

Mas em mim! Que sou vítima do fado?!... Cercada dos mais ásperos tormentos Achas uma alma só, e um só cuidado. (ALORNA, 2007, p. 113)
D. Leonor remete a Eros, o Deus flecheiro, na linha estilística da Arcádia, e se apropria da imagem dos deuses greco-romanos para construir seus versos e corporificar sentimentos. Menciona o prazer, mas como algo que se esgota com a chegada do Amor, que traz agonia, pois, vítima do destino (fado) sua alma está só, cercada de tormentas e impossibilitada de viver o sentimento. $\mathrm{O}$ Fado, as Musas, Tântalo, Aracne e Minerva surgem em seus versos compondo uma constelação de mitos que estruturam não só o seu universo pessoal, mas sua vida, seus amores e sua pátria, e a sociedade onde se move.

O soneto 86 , de D. Leonor, representa bem não só os elementos greco-romanos trazidos pela linha de estilo neoclassicista, mas também as agruras sofridas por ela e por sua família durante o longo período de clausura.
Assim como no Inverno regelado As marítimas Ninfas tiritando Estão o Padre Oceano rodiando No fundo lá do mar frio e salgado
E nem o pescador lasso e forçado Que as praias cuidadoso anda cercando Se apercebe do como estão passando As nereidas no pego prateado
Tais são três corações que su'mergidos Das angústias cruéis, no grau supremo Soluçam sufocados e esquecidos
Ah quanto dura Sorte, quanto temo Que o som dos sentidíssimos gemidos Nem já fira os ouvidos de Palemo. (ALORNA, 2007, p. 192)

O tema deste soneto, bem como o de outros poemas, diz respeito ao sofrimento vivido na clausura não só por ela, mas pela mãe e a irmã. "Tais são três corações que su'mergidos/ Das angústias cruéis, no grau supremo/ Soluçam sufocados e esquecidos". As três sufocam na prisão, vítimas inocentes das artimanhas políticas de seu tempo. Ela compreende e lamenta a sua "dura Sorte", buscando ouvidos que liberte a todos ${ }^{4}$.

Da mesma forma que expressa sua dor, D. Leonor também agradece, quando de sua anistia, à rainha

4 Neste soneto, D. Leonor dialoga com o episódio do Consílio dos Deuses no Oceano (canto VI de Os Lusíadas, est. 15-37), em que Camões narra a admissão do pescador Glauco, filho de Netuno e da ninfa Naïs, entre os deuses do oceano. Glauco amava a bela ninfa Cila, que fora transformada em monstro marinho por Circe, por haver bebido numa fonte envenenada pela feiticeira. 
D. Maria I, quando, enfim, sua família pôde se reunir novamente, após quase duas décadas de separação. $\mathrm{O}$ "Soneto à Anistia" representa o momento em que ela e sua família foram libertadas. O sofrimento expresso no poema anterior dá lugar a uma alegria que atinge não só a família da poetisa, ao ser anistiada, mas, a toda Nação:

Trasíbulo ganhou fama imortal Criando a lei suave d'amnistia À Pátria deu paz, e hoje Maria A promulga de novo em Portugal

Um perdão, prolongando sempre o mal Que a ignorância em sinônimo avalia Não vale esquecimento, ou bastaria Para apagar os danos em geral

Mas tu propício Deus! Tu que criaste Um ser que à lusa terra só convinha As mais puras verdades lhe inspiraste.

A favor da Nação tudo adevinha E se eu cantar puder, quanto a exaltasse Julgarei que a ventura, é também minha. (ALORNA, 2007, p.195).

A alegria advinda da anistia concedida por D. Maria I, recém-elevada ao trono, não é privilégio da poetisa ou de sua família, é benção para a Nação, assim, com maiúscula, ideal platônico de pátria que, acolhendo todos os seus filhos, reconhece as injustiças e elevase de novo diante de Deus. Nesse soneto, não mais os mitos greco-romanos se destacam, mas os mitos pátrios e cristãos: a Pátria, a Nação, Deus. Esses são elementos de um engajamento político bastante evidente na vida e na obra da Marquesa de Alorna, principalmente após sua liberdade e sua vida em sociedade. Esses dois sonetos de cunho político não foram inclusos pelas filhas, em 1844, quando organizaram, em seis volumes, a publicação da obra da mãe. O temor de represálias, provavelmente, as teria levado a não incluir estes e outros sonetos de teor político e/ou de crítica social.

Esse tom engajado também se encontra na obra de Maria Teresa Horta, embora os valores aqui sejam outros, pois há nesta autora um engajamento de gênero que a leva a reconhecer a tradição poética feminina e a resgatar a história da sua ancestral. Esse engajamento com a condição feminina, fá-la seguir os passos da avó sabendo que novos tempos suscitam novas formas de luta, novos temas, novas formas poéticas, novas ousadias. Por isso, Maria Teresa espia a avó, mas também a guia nessas novas veredas da realidade feminina.

Sou tua espia
Sou tua neta
Tua vigia
Sou tua asa
Sou tua guia
Tua passagem
Crio-te a fresta
Abro-te a porta
Teço-te a aura
(HORTA, 2012a, p. 33)

No poema, Maria Teresa Horta espia D. Leonor com olhos de neta que recolhe os resquícios da história da escritora que a precedeu, abrindo seu espaço nessa linha de tradição literária tantas vezes negada às mulheres: uma linha de ajuste com o tempo, uma linha de permanência na história, uma linha de ruptura com a tradição masculina, uma linha de reconstituição histórica, posto que feita de frestas, de vestígios que permitem não só reerguer a personagem D. Leonor, mas a condição feminina daquela época.

Na poesia e na vida, D. Leonor e Maria Teresa Horta apresentam elementos que se cruzam: a participação política ativa, a atenção a uma tradição poética que as antecede, a ousadia em temas e formas, a expressão de suas vozes contra a corrente hegemônica que as oprimia. Cada uma em seu tempo e em sua própria forma, estabelece laços e abre caminhos para a mulher na literatura.

\section{Evocações e prospecções - à guisa de conclusão}

A Marquesa de Alorna e Maria Teresa Horta fazem parte de uma genealogia feminina constituída não só por laços de sangue, mas por ousadias poéticas e biográficas construídas na contramão do que a sociedade espera(va) das mulheres. D. Leonor ousou escolher marido, um estrangeiro, o que lhe possibilitou sair de Portugal e conhecer a Europa, viver amores clandestinos, ter voz num tempo em que se esperava o silêncio das mulheres, pois a elas se destinava um papel de subalternidade. Se a poesia e a fidalguia the asseguravam um lugar de destaque na sociedade portuguesa, a sua postura política e o desassombro de opiniões lhe custaram caro, valendo-lhe o exílio na Inglaterra. A Marquesa temia a 
invasão de Portugal pelas tropas de Napoleão, o que veio a se confirmar, mas o país, no entanto, buscava a neutralidade. $\mathrm{O}$ seu zelo patriótico custou-lhe 11 anos de ausência da pátria.

Regressou a Portugal em 1814 e abriu as portas da sua casa a jovens poetas, como António Feliciano de Castilho (1800-1875) e Alexandre Herculano (18101877). Em 1844, quando da publicação de suas obras, Herculano escreveu na revista $O$ Panorama uma lúcida crítica sobre essa mulher tão notável, colocando o dedo em riste contra o preconceito de gênero. Afirmou: "Aquella mulher extraordinária, a quem só faltou outra pátria, que não esta esquecida terra de Portugal, para ser uma das mais brilhantes provas contra as vans pertenções [sic] de superioridade excessiva do nosso sexo." (apud ANASTÁCIO, 2007, p. 45).

Maria Teresa Horta segue a tradição de sua quinta avó. Ambas são mulheres que têm voz própria e que manifestam a sua rebeldia, assumindo posturas coerentes com seus princípios. Lembramos as agressões sofridas pela escritora, em 1971, pela temática inovadora da poesia de Minha senhora de mim, que não a intimidaram, tendo continuado a escrever, pois, como afirma Cixous, "Os verdadeiros textos de mulheres, textos com o sexo das mulheres [...]" (2010, p. 40; tradução nossa) $)^{5}$. Em 2011, foi laureada com o Prêmio D. Dinis pela publicação do romance As luzes de Leonor, a marquesa de Alorna, uma sedutora de anjos, poetas e heróis, mas recusou-se a receber o prêmio que seria entregue por Pedro Passos Coelho, então primeiro ministro de Portugal, por discordar dos rumos políticos que este traçara para Portugal.

Neste artigo, o olhar foi delineado em busca de temas recorrentes às duas escritoras. D. Leonor, por meio de seus sonetos, Maria Teresa, por meio da ligação com sua ancestral, mas também por meio de temas que, sob outra perspectiva, também se desenvolvem em seus textos. O posicionamento de ambas, a herança de uma tradição masculina, que subvertem e contra a qual se impõem, levam-nas a abordar temas em comum, como o amor. Enquanto a Marquesa de Alorna luta contra o sentimento amoroso, em busca da razão, Maria Teresa Horta o invoca e o preenche de novas nuances. $\mathrm{O}$ engajamento político também é um aspecto bastante forte em ambas. Uma lutando pela pátria portuguesa que almejava, outra lutando contra o preconceito de gênero. A Marquesa de
Alorna e Maria Teresa Horta são escritoras, que carregam em sua obra elementos de liberdade e de subversão que garantem a construção de uma linha de tradição feminina na literatura de língua portuguesa.

\section{Referências}

ALORNA, Marquesa de. Sonetos. Introdução, organização, fixação do texto, notas e bibliografia de Vanda Anastácio. Rio de Janeiro: 7Letras, 2007.

ANASTÁCIO, Vanda. Introdução. In: ALORNA, Marquesa de. Sonetos. Introdução, organização, fixação do texto, notas e bibliografia de Vanda Anastácio. Rio de Janeiro: 7Letras, 2007, 11-84.

BRAGA, Teófilo. História da Literatura portuguesa: os Árcades. Vol. IV. Lisboa: Antília, Casa da Moeda, Secretaria Regional de Educação e Cultura - Região Autónoma dos Açores, 1984.

CHEVALIER, Jean; GHEERBRANT, Alain. Dicionário de símbolos. Trad. de Vera Costa et al. 7 ed. Rio De Janeiro: José Olympio, 1993.

CIXOUS, Hélène Cixous. Le rire de la Méduse et autres ironies. Paris: Galilée, 2010.

HORTA, Maria Teresa. Poesia reunida. Lisboa: Dom Quixote, 2009.

As luzes de Leonor, a marquesa de Alorna, uma sedutora de anjos, poetas e heróis. Lisboa: Dom Quixote, 2011.

$2012 a$.

Poemas para Leonor. Lisboa: Dom Quixote,

$2012 a$.

. As palavras do corpo. Lisboa: Dom Quixote, $2012 b$.

. Efémera. In: - Meninas. Lisboa: Dom

Quixote, 2014. 
MOISÉS, Massaud. A literatura portuguesa. 23 ed. São Paulo: Cultrix, 1987.

NUNES, Maria Leonor. Voo, corpo e mundo. Jornal de Letras. Lisboa, ano XXIX / $\mathrm{n}^{\circ} 1004$, de 25 de março a 7 de abril de 2009, p.14-17.

SARAIVA, António José; LOPES, Óscar. História da Literatura portuguesa. 13 ed. Porto: Porto Editora, 1995.

VASCONCELOS, Helena. Mulheres impossíveis. In: HORTA, Maria Teresa. Poemas para Leonor. Lisboa: Dom Quixote, 2012, p. 9-13.

\section{Notas finais}

1 A título de ilustração, indicamos duas das mais conhecidas: História da Literatura portuguesa, vol. IV, de Teófilo Braga (cf. Braga, 1984, p. 242-255) e a de António José Saraiva e Óscar Lopes (cf. SARAIVA; LOPES, 1996, p. 642).

2 Sugere-se para um estudo mais detalhado sobre a vida e obra da Marquesa de Alorna consultar o texto introdutório de Vanda Anastácio, inserido no livro Sonetos Marquesa de Alorna, organizado pela investigadora portuguesa. Cf. ANASTÁCIO, 2007, p. 11-84.

3 Transcrição das palavras de Maria Teresa Horta proferidas na palestra de abertura feita no XXI Congresso da ABRAPLIP, realizado na USP, em 2007. O texto continua inédito.

4 A Casa Fronteira e Alorna resultou do casamento de D. Leonor Benedita de Oyenhausen e Almeida, condessa de Oyenhausen na Áustria, filha mais velha da Marquesa de Alorna, com D. João José Luís Mascarenhas Barreto. Por esse casamento entrou na Casa de Fronteira a representação da Casa dos Marqueses de Alorna e Condes de Assumar e os títulos de Marqueses de Távora e Condes de São João da Pesqueira, que os Alorna também representavam. Cf. Arquivo Nacional da Torre do Tombo. Disponível em http://digitarq.dgarq.gov.pt/details?id=3909726. Acesso em 26 ago. 2015 .
5 No original "Les vraies textes de femmes, des textes avec des sexes de femmes". (CIXOUS, 2010, p. 40)

Recebido em: 03/03/2017.

Aceito: 19/05/2017. 